The How and the Why 



\title{
The How and the Why
}

\author{
AN ESSAY ON THE ORIGINS \\ AND DEVELOPMENT \\ OF PHYSICAL
}

THEORY

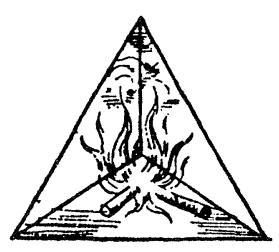

David Park

With drawings by ROBIN B RICKMAN

PRINCETON UNIVERSITY PRESS

PRINCETON, NEW JERSEY 
COPYRIGHT (C) I 988 BY PRINCETON UNIVERSITY PRESS

PUBLISHED BY PRINCETON UNIVERSITY PRESS,

4 I WILLIAM STREET, PRINCETON, NEW JERSEY O 8540

IN THE UNITED KINGDOM:

PRINCETON UNIVERSITY PRESS, CHYCHESTER, WEST SUSSEX

ALL RIGHTS RESERVED

LIBRARY OF CONGRESS CATALOGING-IN-PUBLICATION DATA

PARK, DAVID ALLEN, I9I9-

THE HOW AND THE WHY.

BIBLIOGRAPHY: P.

INCLUDES INDEX.

I. SCIENCE-HISTORY. 2. PHYSICS-HISTORY.

3. ASTRONOMY-HISTORY. I. TITLE.

$$
\text { QI25.P324 } 1988 \quad 509 \quad 87-29 \times 35
$$

ISBN $0-69$ I $-08492-0$

ISBN 0-69I-02508-8 (PBK.)

SECOND PRINTING, I989

THIRD PRINTING, WITH CORRECTIONS, I 990

THIS BOOK HAS BEEN COMPOSED IN LINOTRON SABON

PRINCETON UNIVERSITY PRESS BOOKS ARE PRINTED ON ACID-FREE PAPER AND MEET THE GUIDELINES FOR PERMANENCE AND DURABILITY OF THE COMMITTEE ON PRODUCTION GUIDELINES FOR BOOK LONGEVITY OF THE COUNCIL ON LIBRARY RESOURCES

THE QUOTATION FROM RICHARD WILBUR'S "IPISTEMOLOGY" THAT BEGINS CHAPTER 15 IS FROM

Ceremony and Other Poems,

(C) I950, I 978 BY RICHARD WILBUR.

REPRINTED BY PERMISSION OF HARCOURT BRACE JOVANOVICH, INC.

PRINTED IN THE UNITED STATES OF AMERICA BY PRINCETON ACADEMIC PRESS

$$
\text { I0 } 98776
$$


TO

Clara Claiborne Park

WHO, IN ADDITION TO PROVIDING FACTS, INTERPRETATION, AND CRITICISM, HAS OCCASIONALLY BEEN ABLE

TO MAKE ME THINK CLEARLY 
